\title{
THE LIFE CYCLES OF CRYPTOGAMS
}

\author{
Peter R. BELL
}

SUMMARY: Meiosis and karyogamy are recognized as control points in the life cycle of cryptogams. The control of meiosis is evidently complex and in yeast, and by analogy in all cryptogams, involves progressive gene activation. The causes of the delay in meiosis in diplohaplontic and diplontic organisms, and the manner in which the block is removed remain to be discovered. There is accumulating evidence that cytoplasmic RNA plays an important rôle in meiotic division.

Many features of gametogenesis are still obscure. The tendency to oogamy has provided the opportunity for the laying down of long-lived messenger RNA in the abundant cytoplasm of the female gamete. The sporophytic nature of the developing zygote can in this way be partially pre-determined. There is evidence that this is the situation in the ferns.

Specific molecules (probably arabino-galacto-proteins) on the surface of the plasma membrane are likely to account both for gametic selection, and the readiness with which appropriate gametes fuse. The dikaryotic condition indicates that nuclear fusion is not inevitable following plasmogamy. The ultimate fusion of the nuclei may result from quite simple changes in the nuclear surface. Exposure of lipid, for example, would lead to fusion as a result of hydrophobic forces.

Aberrations of cryptogamic life cycles are numerous. The nuclear relationships of many aberrant cycles are unknown. In general it appears that the maintenance of sporophytic growth depends upon the presence of at least two sets of chromosomes. Conversely the maintenance of gametophytic growth in cultures obtained aposporously appears to be impossible in the presence of four sets of chromosomes, or more. These results raise important problems of the effect of gene dosage on development.

Key words: Meiosis, gametogenesis, gametic fusion, dikaryotic condition, karyogamy, aberrant cycles, gene dosage.

RESUMEN: La meiosis y la cariogamia son reconocidas como puntos de control en los ciclos de vida de las criptógamas. El control de la meiosis es evidentemente complejo y en levaduras, y por analogía en todas las criptógamas, incluye la activación progresiva del gen. Las causas de este retraso en la meiosis de los organismos diplohaplónticos y diplónticos y la manera en que se elimina el bloqueo aun se desconoce. Existe una acumulación de evidencias que indican que el RNA citoplásmico juega un importante papel en la división meiótica.

Muchas características de la gametogénesis están aún oscuras. La tendencia hacia la oogamia ha permitido la oportunidad de establecer la longevidad del ARN mensajero en el abundante citoplasma del gameto femenino. La naturaleza del esporófito desarrollada a partir 
del cigoto puede ser, en este sentido, parcialmente predeterminada. Hay evidencias que esta es la situación en los helechos.

La selección gamética y la prontitud con que se fusionan los gametos apropiados, probablemente se deba a moléculas específicas (quizás arabino-galacto-proteínas) de la superficie de la membrana plasmática. La condición dicariótica indica que la fusión nuclear no es inevitable como consecuencia de la plasmogamia. La fusión definitiva de los núcleos puede resultar de unos cambios bastante simples en la superfice nuclear. La exposición de lípidos, por ejemplo, conduciría a la fusión como resultado de fuerzas hidrofóbicas.

Las aberraciones en el ciclo de vida de las criptógamas son numerosas. Las relaciones nucleares de muchos de los ciclos aberrantes son desconocidas. En general parece que el mantenimiento del crecimiento esporofítico depende de la presencia, por lo menos, de dos juegos de cromosomas. De manera contraria, el mantenimiento del crecimiento del gametófito en cultivos obtenidos apospóricamente parece ser imposible en presencia de cuatro juegos de cromosomas o más. Estos resultados aumentan la importancia de los problemas de la dosificación del gen en el desarrollo.

Palabras claves: Meiosis, gametogénesis, fusión gamética, condición dicariótica, cariogamia, ciclos aberrantes, dosificación del gen.

\section{INTRODUCTION}

It is a remarkable feature of many fungi and of most phototrophic plants that their development involves a life cycle with recognizably different phases. Even organisms as lowly as the slime fungi (Myxomycetes) show such a cycle. Usually the cycle has two phases, but in the red algae (Fig. 1) and mosses three phases are commonly found. We have however to distinguish between morphological and nuclear phases. No matter how many morphological phases there may be in the cycle, the nucleus in all sexual cycles has only two phases; it is either haploid or diploid. When a moss, for example, progresses from the protonemal stage of the gametophyte to the mature form, although there is a sharp change in morphology, there is no change in the number of chromosomes. Striking changes in gene activation may occur without change in chromosome number.

The two sites of phase change in the nuclear cycle can be identified as meiosis and fertilization (karyogamy) respectively. The first leads to the establishment of the haploid phase, and the second to the fusion of nuclei and the restoration of the diploid condition. We are so familiar with these ordered events in the life of the plant that basic problems, such as why a nucleus divides meiotically and not mitotically, and why some nuclei fuse and others do not, tend to be passed over. In this lecture we shall look at some of these questions, and perhaps encourage a more experimental approach to the study of life cycles. 


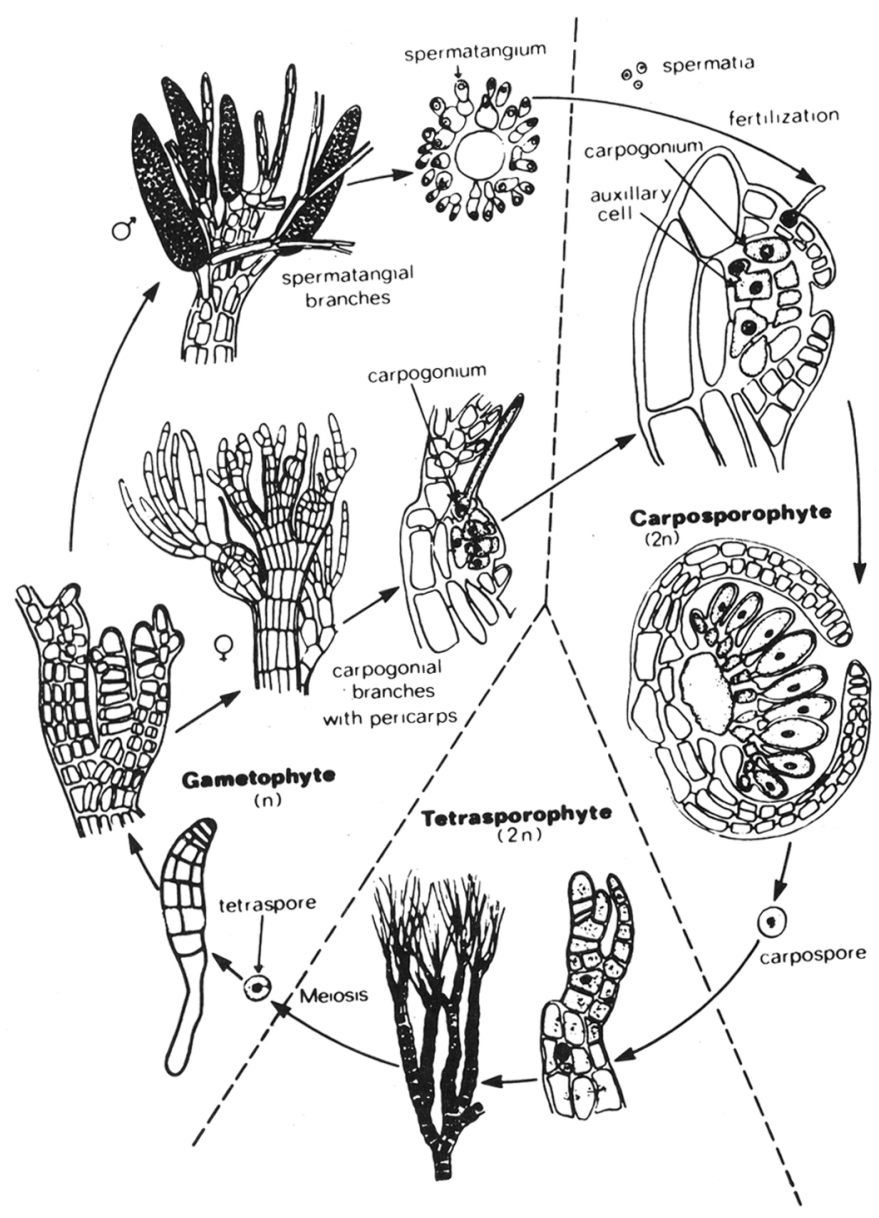

Fig. 1. The life cycle of Polysiphonia, showing two diploid phases and a dioecious haploid phase. From West \& Hommersand (1981).

\section{THE FOUR KINDS OF LIFE CYCLES}

A cycle embodying junction and disjunction of chromosomes may take three forms, depending upon the relative positions of fertilization and meiosis within the cycle. The different kinds of cycle are summarized in Fig. 2.

In the first kind of cycle, termed haplontic, the nucleus for the greater part of the cycle is in the haploid phase. The zygotic nucleus enters meiosis either immediately or after a resting period (Fig. 2, 1). The cycle is then repeated. Examples are provided by many phycomycetes, and algae such as Chlamydomonas and Coleochaete. 


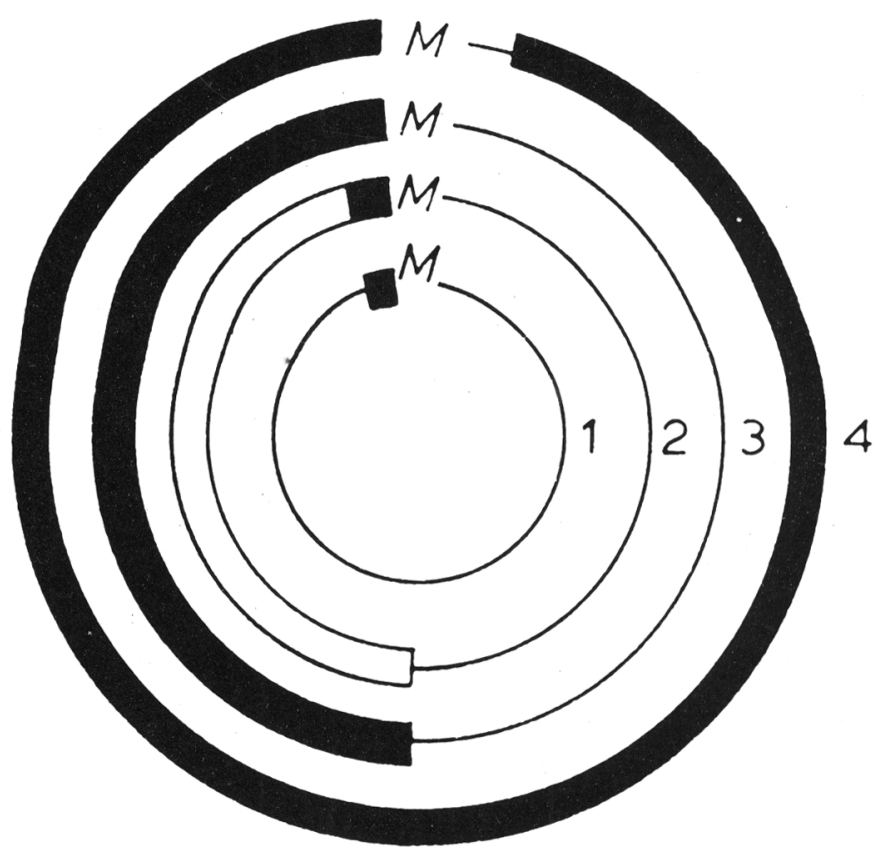

Fig. 2. Diagram showing the four kinds of life cycles (see text). M. meiosis. From Burnett (1976), modified.

In a variant of this kind of cycle there is fusion of cells, but not of nuclei (Fig. $2,2)$. Growth continues with binucleate (dikaryotic) cells, sometimes for very long periods. Ultimately the nuclei fuse, and fusion is followed by meiosis. This kind of cycle is found only in the fungi.

In the third kind of cycle, both phases of the nucleus are accompanied by a notable somatic development (Fig. 2,3). Such cycles are found in some phycomycetes (Allomyces), algae (e.g. Ulva and Ectocarpus), and in all bryophytes and pteridophytes.

The fourth kind of cycle is the converse of the first. Most of the cycle is occupied by the diploid phase (Fig. 2,4). The haplophase is represented solely by gametes. Many oomycetes (e.g. Achlya) and some algae (e.g. Fucus) have this kind of cycle. These organisms are called diplonts.

\section{THE UNIQUENESS OF MEIOSIS}

Of the two points of change in all these sexual cycles the one event that stands out as relatively invariable and open to investigation is meiosis. Surprisingly it is still a fairly mysterious event. Even its location is in some instances uncertain. In the 
Oomycete Phytophthora, for example, it is not clear whether reduction occurs in the gametangia or subsequently in the oospore (Stephenson, Erwin \& Leary, 1974). Nevertheless vital information about meiosis is slowly accumulating. In Saccharomyces, for example, which in Nature exists principally as a diplont, sporulation can be induced by nitrogen starvation in the presence of a respirable sugar. Meiosis is accompanied by the ordered appearance of a number of sporulation-specific proteins (Holloway, Lehman, Primerano. Magee \& Clancy, 1985). This indicates a progressive and fine control of the whole meiotic sequence. Also in yeast a gene has been identified which inhibits meiosis. This is effectively repressed by activation of the «mating-type» locus, and entry into meiosis is then possible (Mitchell \& Herskowitz, 1986).

In haplontic organisms it almost appears as if the nucleus in the diploid condition is in an unstable state, and the zygotic nucleus can do no other but enter meiosis. This impression is given, for example, by the alga Oedogonium. However this may be illusory. Germination of the uninucleate oospore follows chilling, and chilling is known to mobilize enzymes. Meiosis may then be the result of cytochemical changes of the kind being demonstrated in yeast. In experimental conditions oospores of Oedogonium can be germinated without chilling (Mainx, 1931). In these conditions a diploid plant is formed, larger in all its parts than normal. Evidently division of the nucleus has been mitotic. The kind of division undergone by the nucleus of the Oedogonium zygote is therefore open to environmental influences, presumably mediated through the chemistry of the cell.

In cryptogams in which the sporophyte undergoes considerable somatic development the identification of the causes of meiosis is an altogether more difficult problem. There are two aspects: first the induction of the train of development which leads to meiosis, and second the more local events which precipitate meiosis in a particular group of cells. In the bryophytes in natural conditions the sporogonium is determinate. Its development follows a well-defined programme leading ultimately to sporogenesis. Surprisingly the cytochemical characteristics of the cells in the developing archesporium appear not to have been studied in detail. This seems to be an opportunity missed.

In the ferns the problem is complicated by the growth of the sporophyte being indeterminate. Why then do some fronds remain vegetative, while others in whole or part become fertile?. Experiments with Osmunda cinnamomea have shown that explants of juvenile leaves, showing no sign of fertility, can nevertheless be made to form sporangia if cultured in vitro in the presence of high concentrations of sucrose (6-8\%) (Harvey \& Caponetti, 1972). High temperature (c. $26^{\circ} \mathrm{C}$ ) and darkness promote the response. The spores produced in these conditions are fully viable.

Identification of the more intimate causes of meiosis has proved more difficult. In both bryophytes and pteridophytes the sporogenous cells are surrounded by nonsporogenous tissue. It has long been suspected that influences from this tissue contribute to the initiation of meiosis. Firm evidence is still lacking, but indications 
from phanerogams point to the kind of influences which may be at work. In the anther of Lilium, for example, mitotic prophase in the cell lineage destined for microsporogenesis is progressively delayed (Walters, 1985). Ultimately the chromosomes despiralize and the nucleus enters meiosis. This can perhaps be attributed to an inflow of meiosis-inducing substances from the surrounding cells. Initially the effect is to retard prophase, but ultimately their concentration reaches in critical level at which mitosis is no longer possible (Fig. 3). Other experiments with Lilium show that full commitment of the nucleus to meiosis probably occurs quite late in the DNA cycle. Only those microsporocytes in which the G2 phase of the cycle is nearing its end will successfully complete meiosis in vitro (Ito \& Takegami, 1982). Cells with nuclei at earlier stages in the cycle either divide mitotically or behave erratically.

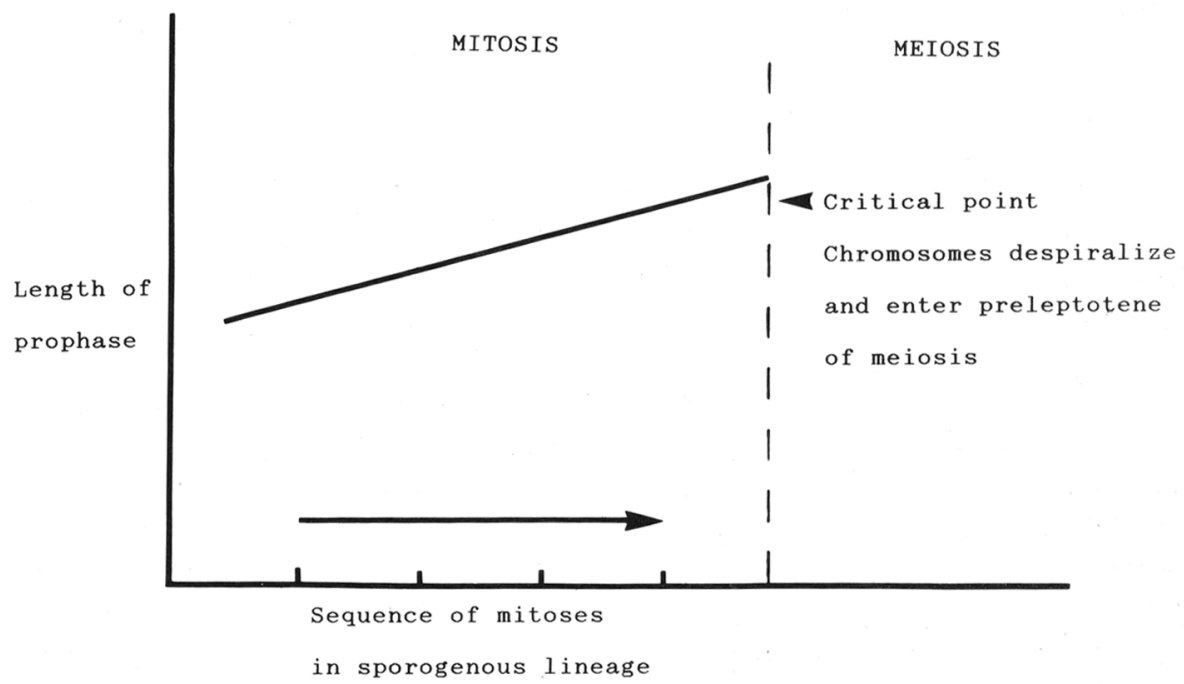

Fig. 3. The induction of meiosis in the anther of Lilium according to Walters (1985).

Also from phanerogams comes tantalizing evidence that ribonucleotides supplied to meristematic tissue cause a meiotic kind of division in place of mitotic. The most recent and convincing demonstration comes from work with root tips of the flowering plant Pterotheca (Mehra \& Kumari, 1986). This has six chromosomes in the diploid condition. Each chromosome of the haploid set is readily recognizable. In the presence of ribonucleotides, and of RNA prepared from yeast, in up to a quarter of the nuclear divisions the chromosomes pair, and subsequently separate into four haploid nuclei. Some of these haploid nuclei continue to divide mitotically. These results are relevant to sporogenesis in both phanerogams and vascular cryptogams since there is often massive depolymerization of cytoplasmic RNA in meiotic prophase (Sheffield $\&$ Bell, 1979). Similar events are recorded during tetrasporogenesis in the red alga 
Dasya (Broadwater, Scott \& Pobiner, 1986), and may be widespread in non-vascular cryptogams. The ribonucleotides generated in this depolymerization may well promote chromosome pairing and facilitate meiosis. Similar conditions may, for example, be present in the fungal basidium which is characteriscally rich in RNA and a site of meiosis. Also noteworthy is that sites of meiosis are often surrounded by thickened walls. These would tend to maintain within the enclosed cells high concentrations of any ribonucleotides released by lysis.

Another striking feature of meiosis in many cryptogams is the long delay in its completion. In sporangia of Allomyces, for example, meiosis may remain suspended in late prophase I for months or even years. This situation may not be uncommon in the resting sporangia and oopores of the haplontic cryptogams and is worthy of further investigation. Also hitherto unexplored is the detailed cytology of the germination of the haplontic algae Volvox, Spirogyra and Chara. In all these instances three of the meiotic products are resorbed and only one swarmer or filament emerges from the spore.

\section{PREPARATIONS FOR FERTILIZATION}

In all cryptogams, except those that have a dikaryotic interval in the cycle, the restoration of the diploid condition depends upon the differentiation of gametes. Fusion is between the gametes or, as in many Oomycetes, the gametangia.

In the simplest situation the gametes, although they may differ in mating type, are morphologically similar. Chlamydomonas provides an example (although the gametes of the + and - strains may differ in ultrastructural details (Martin \& Goodenough, 1975)). Isogamous species are not necessarily haplontic. Ulva, for example, is isogamous and has an isomorphic alternation of generations. It may be true that where an isogamous species has a biphasic cycle it will be isomorphic, but the converse does not hold. The brown alga Dictyota, for example, has an isomorphic cycle but is oogamous.

Anisogamous and oogamous cryptogams frequently show dioecy. This may affect the haplophase (as in Oedogonium), or the diplophase (as in Phytophthora, although here there is fusion of gametangia rather than gametes). Often monoecious and dioecious species are found in the same genus (e.g. Chara).

The factors which lead to the production of gametes are not well understood. In Chlamydomonas culture in a nitrogen-poor medium is usually effective. Instances are known where nutrition affects sex expression in oogamous species. Monoecious gametophytes of homosporous ferns, for example, cultured in poor conditions, will remain largely male. In dioecious species one sex cultured alone will often remain sterile, but when mixed hormonal interaction leads to full sexuality. In Achlya, for example, the female plant stimulates the production of antheridia in the male, and these in turn promote the production of oogonia in the female. A similar interaction 
occurs when compatible mycelia of the Ascomycete Ascobolus confront each other (Bistis \& Raper, 1963). In the dioecious algae also full sexuality is often attained only when the two sexes are cultured together, a familiar example being provided by Oedogonium.

Another well known instance of the mutual regulation of sexuality is the production of antheridiogens by certain homosporous ferns. These hormonal substances, some of which are allied to the gibberellins, are secreted by those gametophytes in a culture which first reach the male phase. They stimulate the massive production of antheridia throughout the whole population. Although largely studied in vitro, there is now evidence of antheridiogen effects in natural populations of gametophytes (Hamilton, 1989).

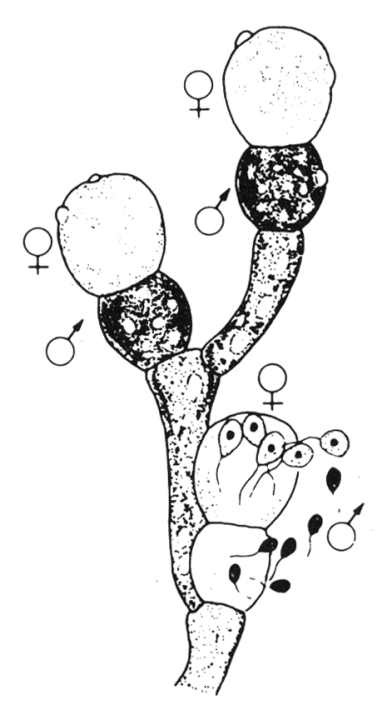

Fig. 4. A fertile branch of Allomyces arbuscula showing the arrangement of the gametangia. From Esser (1976), modified.
Where gametophytes are monoecious the expression of sexuality is often staged, the male appearing first, followed by the female, the two sexes being present for only a short time together. In the homosporous ferns this alternation may be repeated through more than one cycle (Masuyama, 1975). In other ferns and many bryophytes the gametangia are mixed and mature simultaneously. A comparable situation occurs in the fungus Allomyces (Fig. 4). It is not yet possible to identify the local factors which switch gametogenesis into the male or female pathway. In Allomyces arbuscula, where the female sporangium terminates a branch and the male forms below it, it is tempting to envisage a nutritional gradient, the metabolites tending to flow to the tip of the branch. The mitochondria are also more numerous in the apical region. In some other species of Allomyces however the positions of the sporangia are reversed.

In anisogamous and oogamous cycles the larger size of the female gamete is attributable both to more cytoplasm and an enlarged nucleus. Accompanying this difference is a tendency for the female regions to have a higher content of RNA, this sometimes being detectable before sex become expressed (Turian, 1961).

The cytological differences between the gametes reach their extreme in oogamy. A cytoplasm rich in RNA, and an enlarged nucleus with dispersed chromatin are emerging as features of egg cells in a wide range of cryptogams (Bell, 1989). The male gamete by comparison has little cytoplasm and a nucleus consisting almost entirely of condensed chromatin. The augmentation of the female cytoplasm frequently 
involves one or more unequal divisions, most of the cytoplasm remaining with the cell destined to become the egg cell. In Oedogonium, for example, the division preceding the formation of the oogonium cuts off a small suffultory cell. A similar unequal division cuts off a small cell below the archegonium of Chara. In Bulbochaete two suffultory cells are cut off in sequence. In the archegonial canal of the homosporous archegoniates two unequal divisions are also found, one leading to neck canal cell initial and the other to the ventral canal cell. The egg cell at the base of the canal retains almost all the cytoplasm.

Another method of augmenting the female cytoplasm is seen in the centric diatoms. These are diplonts and gametogeneis is meiotic. In female gametogenesis one nucleus degenerates at meiosis I and a second at meiosis II, leaving a single nucleus in a cytoplasm which would otherwise have been shared between four.

The evolution of egg cells with a rich cytoplasm has made possible in cryptogams with heteromorphic life cycles the laying down of messenger RNA in preparation for the next phase of growth. This is undoubtedly the situation in a fern such as Pteridium. RNA accumulates in the egg cell in the final stages of maturation unaccompanied by protein synthesis (Fig. 5). Evidence that a proportion of this is messenger is provided by experiments in which the quality of the RNA is altered by feeding the developirig gamete with the uridine analogue 2-thiouracil. The zygotes then give rise to imperfect embryos which revert spontaneously to gametophytic growth.

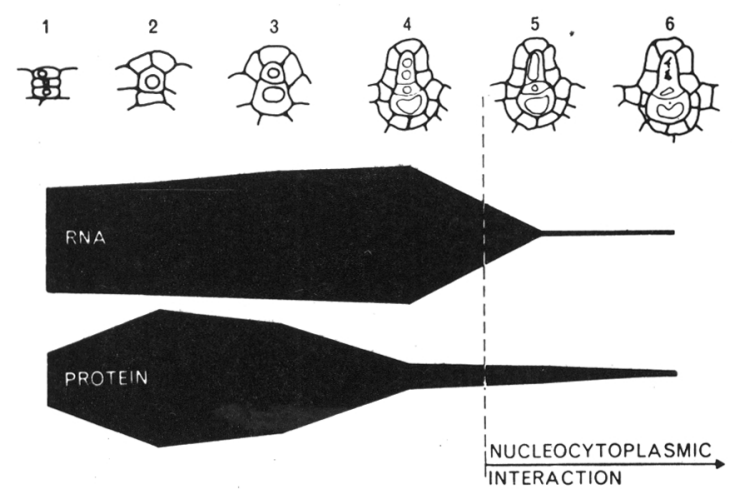

Fig. 5. The synthesis of RNA and protein during oogenesis in Pteridium aquilinum. From the results of Cave \& Bell (1974).

\section{FUSION OF GAMETES}

There are many instances in anisogamous and oogamous cryptogams where male gametes are attracted to the female. Examples of the pheromones responsible for 
these chemotactic effects are sirenin in Allomyces (Carlisle \& Machlis, 1965), ectocarpene in Ectocarpus, and malic acid in a number of polypodiaceous ferns. The precise manner in which these substances direct the motion of the male gametes is for the most part unknown.

The intimate details of gametic fusion have also been little studied. It is not immediately evident why gametes should fuse so readly. Protoplasts, for example, are very reluctant to fuse, and will do so only if their plasma membranes are damaged with polyethylene glycol, or by electrical pulses. It seems very likely that during gametogenesis the plasma membranes are modified so that complementary molecules (probably arabino-galacto-proteins) are present on the surfaces of the two sexes. These would immediately interlock on contact. Such a system is clearly present in Chlamydomonas (notably in relation to the flagella (Adair, 1985)), and more generally in relation to the gamete surface in the brown alga Fucus (Jones, Callow \& Green, 1988). The use of monoclonal antibodies to explore the distribution of gamete surface antigens will undoubtedly reveal much about the molecular mechanics of gametic fusion, and the reasons for species and sexual specificity. The surfaces of the gametic nuclei are presumably modified in a manner corresponding to that of the gametes themselves. Karyogamy would then follow on smoothly from plasmogamy.

A particular problem arises with regard to the dikaryotic stage in Ascomycetes and Basidiomycetes. Why do the complementary nuclei not immediately fuse?. The hypothesis generally advanced is that special gene products keep them apart until the formation of the ascus or basidium. Nuclei, however, like protoplasts, do not spontaneously fuse. An alternative explanation of the delayed nuclear fusion in dikaryotic fungi may be that the genes which determine mating type (and which presumably control the nature of the hyphal surfaces such that complementary strains fuse) leave the nuclei unaffected. The ultimate change in the nuclear surfaces which makes fusion inevitable may not be of the kind seen in gametogenesis, but something far simpler. A loss of the hydrophilic surface proteins, for example, exposing the lipid bilayer of the outer membrane of the nuclear envelope, would release hydrophobic forces which would tend to make the nuclei coalesce. Such a change in the membranes bounding the nuclei might be related to the impending meiosis. Protoplasts extracted from meiocytes, for example, are unique in the readiness with which they fuse (Ito \& Maeda, 1973).

\section{THE BEHAVIOUR OF UNMATED GAMETES}

For those attempting to explain the life cycles of cryptogams in causal terms the existence of many forms of aberrant cycles is an unwelcome complication. The examples are numerous and defy systematic treatment. Nevertheless one aspect of particular interest which might be mentioned is the behaviour of unmated gametes.

Amongst the fungi and algae, particularly those that are isogamous, unmated 
gametes will often behave as spores and regenerate the gametophyte. In Blastocladiella variabilis this property has been utilized to investigate the nature of sex-determination. Although isogamous, male and female plants can be identified by the colour of the gametangia, the male being orange and the female colourless. Female gametes developing without copulation yield both male and female plants. Sex-determination in this species must therefore be phenotypic and not genotypic (Emerson, 1950). Development of unmated gametes, if it occurs at all, is not always normal. In Acetabularia, also isogamous, unmated gametes will grow into giant cells, irregular in shape and approaching $2 \mathrm{~mm}$ in maximum diameter (Dübel, 1985). There is however no morphogenesis. Unmated gametes will sometimes give rise to plants which attempt to behave as sporophytes. An example is provided by Ulva which, as mentioned earlier, is both isomorphic in its life-cycle and isogamous in reproduction. Gametes developing without fertilization may yield plants whose sporophytic nature is revealed by abortive meiosis in the zoosporangia (Tanner, 1981). Similar behaviour has been observed in Allomyces. Zoospores from resistant sporangia (in which meiosis normally occurs) can be made to develop into sporophytes by variation of the period of drying and the concentration of the medium (Emerson, 1950). Nothing is known of the chromosome relationships in this instance.

In the oogamous cryptogams the male gametes are probably too specialized and reduced to develop further in culture, and no instances are known. The parthenogenetic development of egg cells in the algae has been observed, but little is known about the consequences in the life cycle. It has not been possible however to confirm an old report that egg cells of Fucus could be stimulated into development by chemical means (Evans, Callow \& Callow, 1982). It is also doubtful whether the egg cells of bryophytes and homosporous pteridophytes are capable of parthenogenetic growth (Bell, 1989). The direct transition from gametophyte to sporophyte in all convincingly established instances is accomplished by way of a vegetative outgrowth, with no tissue discontinuity between one phase and the next.

In bryophytes the ability of gametophytes to yield sporogonia directly appears to depend upon the presence of at least two basic chromosome complements in the nucleus, either similar, or, in the instance of a hybrid, dissimilar. This may also be true of the ferns. The readiness to change from gametophyte to sporophyte certainly increases with the polyhaploid level of the gametophyte. In Polypodium aureum, for example, normal haploid prothalli will not display apogamy, but diploid prothalli (produced aposporously) can be made to change their form of growth by arranging the lighting so that they grow upright (Heilbronn, 1932). Tetraploid prothalli give rise to sporophytic outgrowths spontaneously, and are difficult to maintain in the gametophytic state. In bryophytes diploid gametophytes, raised aposporously from sporophytes, will often give rise to sporophytes if the medium is allowed to dry. Bizarre growths can sometimes be obtained by successive dehydration and rehydration (Fig. 6). 


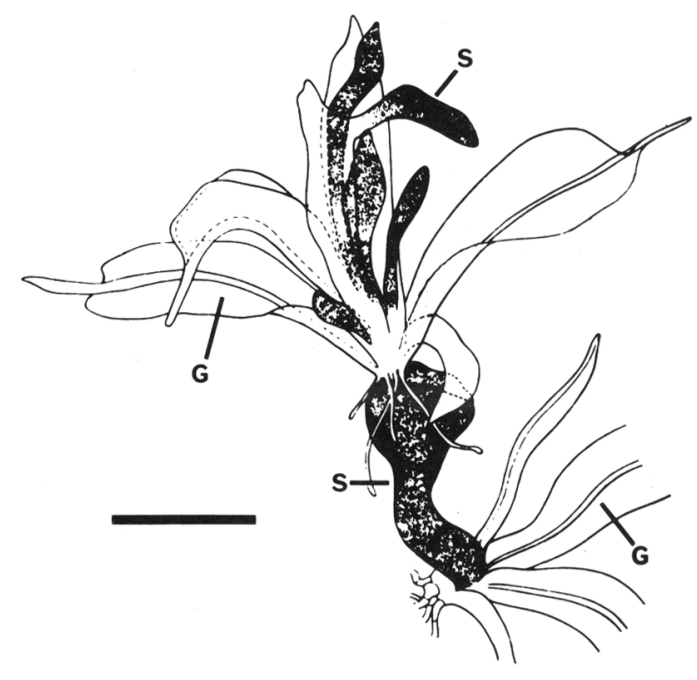

Fig. 6. Diploid Phascum cuspidatum obtained by aposporous regeneration. Successive gametophytic $(\mathrm{G})$ and sporophytic $(\mathrm{S})$ growths obtained by varying the hydration of the medium. Scale $0.5 \mathrm{~mm}$. From von Wettstein (1942).

\section{CONCLUSION}

This lecture has probably revealed the depth of our ignorance about the physiology of the cryptogam life cycle, rather than startling advances in knowledge. At least we can now identify with fair certainty the control points. Crucial to an understanding of the normal cycle will be an explanation of meiosis, of the factors which initiate and control this unique form of nuclear division, and why they are immediately operative in haplonts but long delayed in diplonts. It seems likely the current investigations of gamete surfaces by monoclonal antibodies will reveal relatively soon why male and female gametes find each other irresistable. In organisms with biphasic cycles, particularly where they are heteromorphic, characterization of the messenger RNAs in the female cytoplasm will probably show that the activation of the genes responsible for the features of the sporophytic phase begins in oogenesis. The discovery that, although gametophytic morphology and fuction can exist in the presence of chromosome numbers normally associated with the sporophyte, the readiness with which a direct transition from gametophyte to sporophyte will take place is not independent of chromosome number raises important issues of gene dosage effects.

Although success in elucidating the life cycles of cryptogams may appear limited, the nature of the problems to be solved are now much clearer. This in itself is an achievement upon which much can be built. 


\section{REFERENCES}

ADAIR, W.S. -1985- Characterization of Chlamydomonas sexual agglutinins. J. Cell Sci. Sppl. 2. 233-260.

BELL, P.R. -1989- The alternation of generations. Adv. Bot. Res., 16:55-93.

BISTIS, G.N. \& J.R. RAPER -1963- Heterothallism and sexuality in Ascobolus stercorarius. Amer. J. Bot., 50:880-891.

BROADWATER, S.T., J. SCOTT \& B. POBINER -1986- Ultrastructure of meiosis in Dasya baillouviana (Rhodophyta). I. Prophase I. J. Phycol., 22:490-500.

BURNETT, J.H. -1976- Fundamentals of Mycology. Arnold, London.

CARLISLE, M.J. \& L. MACHLIS -1965- The response of male gametes of Allomyces to the sexual hormone sirenin. Amer. J. Bot., 52:478-483.

CAVE, C.F. \& P.R. BELL -1974- The synthesis of ribonucleic acid and protein during oogenesis in Pteridium aquilinum. Cytobiologie, 9:331-343.

DÜBEL, S. -1985- Characterization of haploid Acetabularia cells. Eur. J. Cell Biol., 38:328334.

EMERSON, R. -1950- Current trends of experimental research on the aquatic phycomycetes. Ann. Rev. Microbiol., 4:169-200.

ESSER, K. -1976- Kryptogamen. Springer, Berlin.

EVANS, L.V., J.A. CALLOW \& M.E. CALLOW -1982- The biology and biochemistry of reproduction and early development in Fucus. Prog. Phycol. Res., 1:67-110.

HAMILTON, R.C. -1989-Evidence of antheridiogen effect in naturally occurring gametophyte populations. Amer. J. Bot., 76:203.

HARVEY, W.H. \& J.D. CAPONETTI -1972- In vitro studies on the induction of sporogenous tissue on leaves of the cinnamon fern. I. Environmental factors. Can.J.Bot., 50:2673-2682.

HEILBRONN, A. -1932- Polyploidie und Generationswechsel. Ber. dtsch. bot. Ges., 50:289299.

HOLLOWAY, B.L., D.J. LEHMAN, D.A. PRIMERANO, P.T. MAGEE \& M.J. CLANCY 1985- Sporulation-regulated genes of Saccharomyces cerevisiae. Curr. Genet., 10:163169.

HOMMERSAND, M.H. \& J.A. WEST -1981- Rhodophyta: life histories. In: Lobban, C.S. \& Wynne, M.J. (Eds.). The Biology of Seaweeds. Univ. Cal. Press, Berkeley \& Los Angeles.

ITO, M. \& M. MAEDA -1973- Fusion of meiotic protoplasts in liliaceous plants. Exptl. Cell Res., 80:453-455.

ITO, M. \& M.H. TAKEGAMI -1982- Commitment of mitotic cells to meiosis during the G2 phase of premeiosis. Plant Cell Phys., 23:943-952.

JONES, J.L., J.A. CALLOW \& J.R. GREEN -1988- Monoclonal antibodies to sperm surface antigens of the brown alga Fucus serratus exhibit region-, gamete-, species- and genuspreferential binding. Planta, 176:298-306.

MAINX, F. -1931- Physiologische und genetische Untersuchungen an Oedogonien. Z. Bot., 24:481-527.

MARTIN, N.C. \& V.W. GOODENOUGH-1975-Gametic differentiation in Chlamydomonas reinhardii. I. Production of gametes and their fine structure. J. Cell Biol., 67:587-605.

MASUYAMA, S -1975- The sequence of the gametangium formation in homosporous fern gametophytes. Sci. Rep. Kyoiku Daigaku, Tokyo. Sec. B 16:47-69.

MEHRA, P.N. \& L. KUMARI -1986- Induced meiotic reductions in root tips. III. Effect of pyrimidine derivatives and RNA. Cytologia, 51:457-466. 
MITCHELL, A.P. \& I HERSKOWITZ -1986- Activation of meiosis and sporulation by repression of the RME-1 product in yeast. Nature, 319:738-742.

SHEFFIELD, E. \& P.R. BELL -1979- Ultrastructural aspects of sporogenesis in a fern, Pteridium aquilinum (L.) Kuhn. Ann. Bot., 44:293-405.

STEPHENSON. L.W., D.C. ERWIN \& J.V. LEARY -1974- Meiotic configurations in the oospore of Phytophthora capsici. Can. J. Bot., 52:2141-2143.

TANNER, C.E. -1981- Chlorophyta: life histories. In: Lobban, C.S. \& Wynne, M.J. (Eds.) The Biology of Seaweeds Pp. 218-247. Univ. Cal. Press, Berkeley \& Los Angeles.

TURIAN, G. -1961- Nucleic acids and sexual differentiation in Allomyces. Nature, 190:825.

WALTERS, M.S. -1985- Meiosis readiness in Lilium. Can. J. Genet. Cytol., 27:33-38.

WETTSTEIN, F. VON -1942- Über einige Beobachtungen und experimentelle Befunde bei Laubmoosen. Ber. dtsch. bot. Ges., 60:399-405.

(Melilla, Septiembre de 1989)

Dirección del autor: Department of Botany and Microbiology, University College. London WC1E 6BT. 